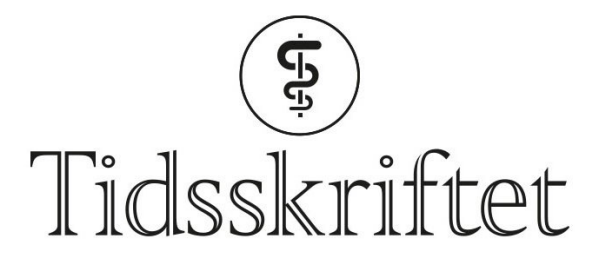

DEN NORSKE LEGEFORENING

\title{
Hvordan opplever pasienter behandling med nevroleptika?
}

FRA ANDRE TIDSSKRIFTER

KETIL SLAGSTAD

Tidsskriftet

Effekten av nevroleptika oppleves svært ulikt - fra mindre hallusinasjoner og bedre livskvalitet til sløvhet og initiativløshet.

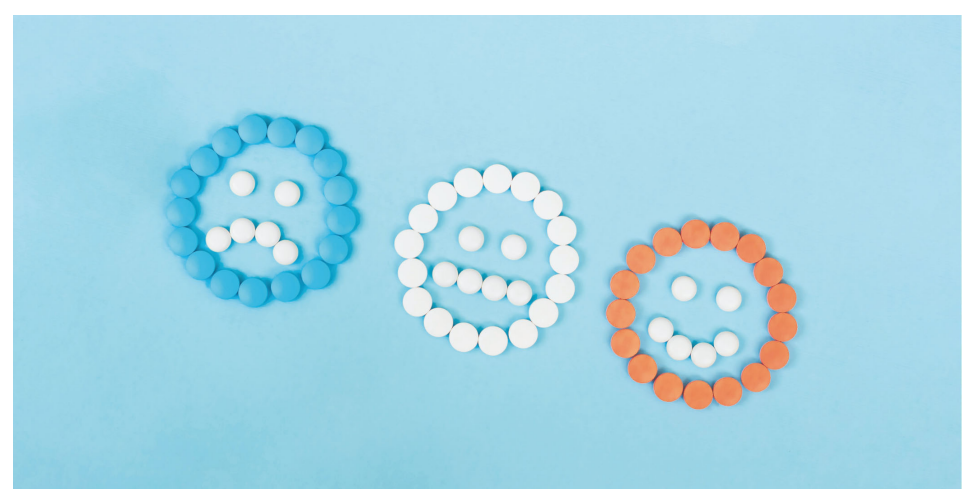

Illustrasjon: Olga Chalovskaia / iStock

Nevroleptika blir ofte anbefalt i behandling av psykoselidelser for å lindre symptomer og forebygge tilbakefall. Hvordan opplever pasienter å bruke disse legemidlene? En systematisk oversikt og metaanalyse som nylig ble publisert i tidsskriftet Social Psychiatry and Psychiatric Epidemiology, omfattet 35 kvalitative studier om pasienters opplevelser av legemiddelbehandling med nevroleptika (1). Flertallet av studiene gjaldt pasienter med psykoselidelser, og funnene ble gjenstand for en såkalt kvalitativ metasyntese.

Flertallet av pasientene fortalte at de følte seg numne, nedsløvede og initiativløse med kognitive vansker og avflatet følelsesliv. Mange rapporterte om vektøkning og tap av sexlyst. En gjennomgående beskrivelse var «å føle seg som en zombie», og for en del pasienter inkluderte dette en opplevelse av å ha «mistet seg selv» og evnen til å kunne relatere seg til andre. Mange pasienter rapporterte at det å ta nevroleptika gjorde at de følte seg som pasienter med kronisk sykdom og del av en stigmatisert gruppe.

Samtidig beskrev mange at nevroleptika reduserte hørselshallusinasjoner, bedret livskvaliteten og økte evnen til å tenke klart. For en del pasienter fungerte nevroleptika som et skjold som holdt psykotiske opplevelser unna. Andre opplevde at nevroleptika hadde gitt dem et nytt liv, og at de følte seg mer som «sitt gamle jeg». Et gjennomgående funn var at pasienter opplevde at de hadde liten autonomi og medbestemmelsesrett i valg av behandling. Andre rapporterte at de aktivt deltok i slike vurderinger sammen med 
behandler.

- Denne studien bekrefter at mange pasienter opplever at nevroleptika reduserer plagsomme psykotiske symptomer. For noen er legemidler helt avgjørende for å kunne finne tilbake til seg selv, hverdagen og et sosialt liv, sier Kristin Lie Romm, som er psykiater og førsteamanuensis ved Universitetet i Oslo.

- Nevroleptika virker på flere nevrotransmittersystemer samtidig, og noen pasienter opplever derfor uønskede effekter. Det har vi nok ikke vektlagt tilstrekkelig i behandlingen. Som behandlere bør vi i større grad nærme oss den enkelte pasients opplevelser med en åpen og utforskende holdning. Vi må være oppriktig interessert i svarene vi får, selv om det gir oss noen utfordringer, sier hun.

- Behandling må hvile på en helhetlig vurdering av effekt og bivirkninger opp mot felles mål for tilfriskning. Dette er en krevende oppgave som innebærer prøving og feiling og ikke minst at alternativer til medikamentell behandling er tilgjengelige. Behandlingen blir aldri god hvis effektene av legemidlene oppleves som en større belastning enn symptomene, sier Romm.

\section{LITTERATUR:}

1. Thompson J, Stansfeld JL, Cooper RE et al. Experiences of taking neuroleptic medication and impacts on symptoms, sense of self and agency: a systematic review and thematic synthesis of qualitative data. Experiences of taking neuroleptic medication and impacts on symptoms, sense of self and agency: a systematic review and thematic synthesis of qualitative data. Soc Psychiatry Psychiatr Epidemiol 2019 doi: 10.1007/soo127-019-01819-2. [PubMed][CrossRef]

Publisert: 17. april 2020. Tidsskr Nor Legeforen. DOI: 10.4045/tidsskr.20.0051

(C) Tidsskrift for Den norske legeforening 2020. Lastet ned fra tidsskriftet.no 